\title{
Productivity Demand Shocks And Asia-Pacific Real Exchange Rates
}

Ordean Olson, Nova Southeastern University, USA

\begin{abstract}
The evidence for a productivity-based explanation for real exchange rate behavior of East Asian currencies is examined using sectoral output and employment data, relative prices and relative productivities for China, Indonesia, Japan, Korea, Malaysia, Philippines, Singapore, Taiwan, and Thailand. Time series regressions of the real exchange rate on relative productivity ratios indicate significant relationships for the Philippines, Hong Kong, Thailand, Singapore, Taiwan and Korea. Only when augmenting the regressions with real oil prices are significant relationships obtained for Indonesia and Japan. Panel regression results are less supportive of a relative productivity view of real exchange rates except for Hong Kong, China and Thailand. Surprisingly, government spending does not appear to be a determinant of real exchange rates except for the countries of Malaysia, the Philippines, Taiwan and Thailand.
\end{abstract}

Keywords: Balassa-Samuelson growth model, exchange rates, productivity, East Asia

\section{INTRODUCTION}

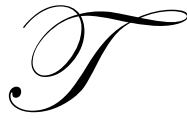

he study of long-run real exchange rate determination has enjoyed a rebirth in recent years. With the development of detailed sectoral databases, economists have been able to analyze the empirical foundations for productivity based models of the real exchange rate, such as those of Balassa (1964) and Samuelson (1964). These models imply that real exchange rate appreciation should be correlated with differentials in traded/nontraded-sector productivity growth.

In this paper, I examine whether one can verify the relevance of the Balassa-Samuelson effect in East Asian countries by using sectoral productivity, government spending, gross domestic product and price levels. The EastAsian economies are exactly the type for which the Balassa-Samuelson effect would apply: economies characterized by rapid growth, presumably due to rapid manufacturing (and hence traded) sector productivity growth.

\section{LITERATURE REVIEW AND FORMULATION OF TIME SERIES REGRESSIONS}

The starting point for most investigations of the linkage between the relative price of nontradables and the real exchange rate relies upon the following construction: Let the log aggregate price index be given as a weighted average of $\log$ price indices of traded $(\mathrm{T})$ and nontraded $(\mathrm{N})$ goods.

$\mathrm{P}_{\mathrm{t}}=(1-\&) \mathrm{P}_{\mathrm{t}}^{\mathrm{T}}+\& \mathrm{P}_{\mathrm{t}}^{\mathrm{N}}$

where $\&$ is the share of nontraded goods in the price index. Suppose further that the foreign country's aggregate price index is similarly constructed:

$\mathrm{P}_{\mathrm{t}}^{*}=\left(1-\&^{*}\right) \mathrm{P}_{\mathrm{t}}^{\mathrm{T}^{*}}+\&^{*} \mathrm{P}_{\mathrm{t}}^{\mathrm{N}^{*}}$

Then the real exchange rate is given by:

$Q_{t}=\left(S_{t}+P_{t}^{*}-P_{t}\right)$ 
Where $\mathrm{S}$ is the $\log$ of the domestic currency price of foreign currency. For $\mathrm{a}=\mathrm{a}^{*}$, the following holds:

$\mathrm{Q}_{\mathrm{t}}=\left(\mathrm{S}_{\mathrm{t}}+\mathrm{P}_{\mathrm{t}}^{\mathrm{T}}-\mathrm{P}_{\mathrm{t}}^{\mathrm{T}^{*}}\right)-\&\left\{\left(\mathrm{P}_{\mathrm{t}}^{\mathrm{N}}-\mathrm{P}_{\mathrm{t}}^{\mathrm{T}}\right)-\left(\mathrm{P}_{\mathrm{t}}^{\mathrm{N}^{*}}-\mathrm{P}_{\mathrm{t}}^{\mathrm{T}^{*}}\right)\right\}$

Although there are many alternative decompositions that can be undertaken, equation (4) is the most relevant since most economic models make reference to the second term as the determinant of the real exchange rate. The first term is assumed to be zero by purchasing power parity (PPP) as applied to traded goods. Engel (1995) examines the relative contributions of both of these components to the variability of the US real exchange rate against other G-7 currencies, and finds that the first component accounts for almost all of it, over many horizons, and for many price indices. Isard and Symansky (1996) undertake a slightly different decomposition, allowing the nontraded shares (\&'s) to change over time. This procedure yields a breakdown of the real exchange rate changes into three components: (i) changes in the relative price of traded goods; (ii) changes in the relative price of traded to nontraded goods; and (iii) changes in share weights (\&'s). The results are consistent with Engel's study in that the first term accounts for almost all of the movements in the real exchange rate for China, Indonesia, Japan, Philippines, and Thailand. Chin (1996) examines East Asian exchange rates and using cointegration techniques finds that there is some evidence that in the long-run, relative prices of tradables and nontradables do explain real exchange rates for certain currencies.

The use of the relative price of tradables and nontradables within the Balassa-Samuelson framework will be incorporated in this study. The relative price of nontradables and tradables will be determined by productivity differentials. Capital is perfectly mobile internationally, and factors of production are free to move between sectors. Summarizing out for relative pries yields:

$\left(S_{t}+P_{t}^{T}-P_{t}^{T^{*}}\right)-\&\left[\left(Q^{N} / Q^{T}\right) a_{t}{ }^{T}-a^{N}\right]+\&\left[\left(Q^{N^{*}} / \theta^{\left.T^{*}\right)} a_{t}{ }^{T *}\right.\right.$

Where $\mathrm{a}^{\mathrm{i}}$ is total factor productivity in sector $\mathrm{i}$.

Most researchers have proceeded under the assumption that the first term is $\mathrm{I}(0)$. This implies cointegrating relationships of the form:

$Q^{t}=-\&\left(P_{t}^{N}-P_{t}^{T}\right)+\&\left(P_{t}^{N^{*}}-P_{t}^{T^{*}}\right)$

and

$Q_{t}=-\&\left[a_{t}^{T-} a_{t}^{N}\right]+\&\left[a_{t}{ }^{\mathrm{T}}-a_{t}^{N^{*}}\right]$

Where the production functions in the tradable and nontradable sectors are assumed to be the same, the $\theta$ cancel out in equation (7). Equation (6) and (7) will motivate the empirical work. Both equations have been exploited extensively. Equation (6) has been examined by Kakkar and Ogake (1994) for several exchange rates. Equation (7) has been estimated by Hsieh (1982) and Marston (1990).

\section{DATA CONSTRUCTION}

The countries examined include China, Indonesia, Japan, Korea, Malaysia, the Philippines, Singapore, Thailand, Taiwan and the US for the period 1970-2007. The data are drawn from a variety of sources. The nominal exchange rate is the bilateral period average, expressed against the US\$ (in \$/f.c.u.). Price levels are WPI's and GDP deflators drawn from the World Bank's World Tables. The real exchange rates are then expressed in terms of CPI's. The prices of tradables and nontradables are proxied by the WPI and CPI respectively. The CPI includes mostly services, construction, and transportation, respectively. The data are calculated as the ratio of nominal to real (in 1987 domestic currency units) sectoral output, as reported in World Tables, except in certain cases, such as Malaysia and Taiwan, where the Asian Development Bank's Key Indicators of Developing Asian and Pacific Countries are used. The exchange rates are expressed in inverse terms (foreign currency unit/US) in these figures; hence the country pairs should be positively coordinated according to the theory described above. 
Previous attempts to test the Balassa-Samuelson Model's predictions regarding East Asian productivity levels and currencies have been hampered by the lack of sectoral productivity data. Consequently, previous researchers have resorted to proxies, such as GDP per capita, or aggregate productivity. Total factor productivity is employed in this model as with Bosworth and Collins (1997) who argue for the use of total factor productivity data based on an economy-wide basis.

The total factor productivity data is drawn from the World Tables, the ABD Key Indicators, and for the developed countries, the International Labour Office's Yearbook of Labour Statistics.

\section{ECONOMETRIC SPECIFICATION}

Kremers, Ericksson and Dolado (1992) employ the cointegrating vector a priori. The test for cointegration can then be applied quite simply by evaluating the $t$-statistic on the error correction term. As Zivot (1996) has pointed out, the distribution for this $t$-statistic depends upon a number of assumptions, most importantly on the validity of the a priori cointegrating vector. Since in the absence for a role for demand side shocks,

$p_{t}{ }^{n}-p_{t}{ }^{T}=a_{t}{ }^{T}-a_{t}{ }^{n}$

Relative productivity is substituted for relative prices, and the constraint $\&=0.5$ is imposed. This implies that the share of nontradables in the aggregate price index (CPI) is one-half. The equation for relative productivity is estimated and entered separately. Zivot (1996) shows that if this variable enters in significantly, then the imposed cointegrating vector is invalid. For the instances in which this is true, I estimate the equation unconstraining the cointegrating vector and using NLS.

To summarize, the unconstrained specification is:

$\Delta \mathrm{q}_{\mathrm{t}}=\mathrm{U}+\Sigma \mathrm{Y}_{\mathrm{i}} \Delta \mathrm{q}_{\mathrm{t}-\mathrm{I}}+\Sigma \mathrm{s}_{\mathrm{j}} \Delta \&_{\mathrm{t}-\mathrm{j}}$

$+\Phi\left[\mathrm{q}_{\mathrm{t}-\mathrm{I}}+\& \mathrm{~s}_{\mathrm{t}-1}\right]+\mathrm{V}_{\mathrm{t}}$

$S_{\mathrm{t}}=\left(\mathrm{a}^{\mathrm{T}}-\mathrm{a}^{\mathrm{N}}\right)-\left(\mathrm{a}^{\mathrm{T} *}-\mathrm{a}^{\mathrm{N}^{*}}\right)$

And the constrained specification is:

$\Delta \mathrm{q}_{\mathrm{t}}=\mathrm{U}_{=} \Sigma \mathrm{Y}_{\mathrm{I}} \Delta \mathrm{q}_{\mathrm{t}-\mathrm{I}}+\Sigma \mathrm{s}_{\mathrm{j}} \Delta \varsigma_{\mathrm{Tt}-\mathrm{j}}$

$+\left[\mathrm{q}_{\mathrm{t}-\mathrm{I}}+0.5 \mathrm{~s}_{\mathrm{tt}-1}\right]+\mathrm{V}_{\mathrm{t}}$

\section{EMPIRICAL RESULTS}

We examine both the short and long-run behavior of each of the series using the relative prices, relative productivities, and nominal exchange rates. To determine whether each of the series has stationary deviations from a determined trend augmented Dickey-Fuller (1979) unit root tests are carried out. If there are stochastic trends, the Balassa-Samuelson model implies that tested series must share the same stochastic trend and must be cointegrated. The null hypothesis that the estimated residuals have a unit root is tested as suggested by Engle and Granger (1987) and Phillips and Ouliaris (1990).

We examine the trend behavior of each series, and find that there is evidence against the null hypothesis of a unit root in relative productivities, relative prices of goods and nominal exchange rates. The results are shown in Table 1. Almost all the series appear to be integrated on order 1 according to ADF tests. The exceptions are the Thailand productivity differential, and the Thailand, Malaysia and the Philippines real exchange rates. All of the others are at $90 \%$ significant levels. I will proceed under the presumption that all series are I(1). The LR series are shown in Table 2. The LR type tests for cointegration indicate the series to be on order I(1). The exceptions are the Japanese, Indonesia, and Malaysia exchange rates. All of the others are at $99 \%$ or $95 \%$ significant levels respectively. I will proceed under the assumption that all series are I(1). 
The cointegration tests of Johansen (1988) indicate that there is one cointegrating vector in all of the cases with the exception of Japan, Indonesia and Malaysia. The results of the tests are shown in Table 2. The tests are significant at the $99 \%$ level for Thailand, Singapore, Taiwan and Korea. The Philippines, China and Taiwan are significant at the $95 \%$ level.

Regressions indicated that the $\alpha=0.5$ restriction was violated by the data for Japan, Indonesia and Malaysia. Hence, regressions for the form of (8) were estimated for all real exchange rates except those currencies, in which case equation (9) was implemented. In general $\mathrm{k}=\mathrm{j}=1$ (except where noted). The results in Table 3 indicate that the real exchange rate does appear to be cointegrated with relative traded/nontraded productivity levels for Japan, Malaysia and the Philippines. Exchange rates for Singapore and Taiwan appear to be unexplained by relative productivity differentials. These results for Taiwan contrast strongly with those obtained by $\mathrm{Wu}(1996)$ who found that the real exchange rate is cointegrated with relative productivities and relative unit labor costs, expressed in a common currency.

The government spending variable was added and allowed to affect the contemporaneous real exchange rate. The results of the re-specification show with the additional variable the significant level for the error correction term is reduced for some countries (the data is not shown but is available upon request). The data on tradable and nontradable goods was only available for Hong Kong, Indonesia, Korea, Malaysia, the Philippines, Singapore, Taiwan and Thailand. All were statistically significant with the exception of Malaysia, Taiwan and Thailand. The increase in government spending to GDP ratio causes depreciation of the currencies for Malaysia, Taiwan and Thailand. This is consistent with most countries if the spending is on nontradable goods.

In productivity-based studies of Chin and Johnson (1996), and Degregorio and Wolf (1994) real oil prices were a factor in determining real exchange rates. To show this effect the real oil price variable was added to the model. The results of adding this variable are shown in Table 2. Real oil prices are shown to be a significant factor for Indonesia (an oil exporter) and Japan (an oil importer) and are significant at 95\% significant level. The results of reestimating the model are shown in Table 3. Real oil prices prove to be a significant factor in Indonesia (oil exporter), and Japan and Korea (oil importers). The direction of the effects is consistent with priors. Increases in oil prices appreciates the Indonesian Rupiah against the US\$, and depreciates the Yen (in both the short and long run) and Won (in the short run).

The evidence is fairly strong for a productivity-based model with the addition of the real oil price variable in the East Asian region. Indonesia, Japan, Korea, Malaysia, Hong Kong, Singapore, Thailand, Taiwan and the Philippines appear to follow the general pattern.

\section{IMPULSE RESPONSES}

This study follows the procedure of Blanchard \& Quah (1989) using a VAR with a constant term (with long-run restrictions for the effects of shocks) to estimate the reduced-form model in order to replicate the original results as closely as possible. Figures 1,2 and 3 show the implied impulse response functions for the BlanchardQuah procedure together with approximately $95 \%$ confidence intervals obtained from Hall's bootstrap method using 2,000 replications. The results show that positive supply shocks (total factor productivity) increase the real exchange rate in the case of Hong Kong, China, Malaysia and the Philippines in the short-run while increasing Korea in the long-run.. The interval estimate indicates that the exchange rate increases significantly during the first 6 months then levels off for Hong Kong, China, Malaysia and the Philippines. While interval estimate indicates that for Korea the exchange rate is level and then only increases significantly after a period of 18 months.

\section{THE RELATIVE PRICE OF TRADABLES/NONTRADABLES}

The relationship between the real exchange rate and the relative price of tradables versus nontradables was also investigated using the procedure of Blanchard \& Quah (1989). Data was only available for the countries of Indonesia, Korea, and Malaysia the Philippines and Thailand. The results show the implied impulse response functions for the Blanchard-Quah procedure together with approximately $95 \%$ confidence intervals obtained from Hall's bootstrap method using 2,000 replications (the data is available upon request). The results indicate that 
positive supply shocks (relative price of tradables versus nontradables) have significant effect on the real exchange rates of Indonesia, Korea, Malaysia, the Philippines and Thailand. The Philippines and Malaysia show an increase in the exchange rate in the short-run while Thailand, Indonesia and Korea show a decrease in the real exchange rate in the short-run.

\section{CUSUM TESTS}

The so-called CUSUM, that is, the cumulative sum of recursive residuals can reveal structural changes. The CUSUM was proposed for this purpose by Brown, Durbin \& Evans (1975). If the CUSUM wanders off too far from the zero line, this is evidence against structural stability of the underlying model. A test with a significance level of about 5\% is obtained by rejecting stability if CUSUM, crosses the lines (see e.g., Kramer \& Sonnberger (1986), Kramer, Ploberger \& Alt (1988), or Granger \& Terasvirta (1993, p. 85).

In Figure 4 CUSUM tests are shown for the Philippines and China of the exchange rate and total factor productivity series. They do not give any indication of model instability because the CUSUM's do not leave the respective areas between dashed lines (Cusum tests for Japan, Singapore, Korea, Malaysia, Taiwan and Thailand are not shown but are available upon request).

\section{CONCLUSIONS}

The purpose of this study was to examine the evidence of a productivity-based explanation for long-run movements in East-Asian real exchange rates. The results show some evidence although not conclusive as it relates to China and Thailand. Also, there are large movements away from the equilibrium rate as predicted by either the relative price of tradables to nontradables or relative productivities. It should be noted that there is substantial persistence in the relative prices of traded goods and their effect on real exchange rates. This would increase the evidence for productivity-based real exchange rates for the relative price of tradables to nontradables.

\section{AUTHOR INFORMATION}

Dr. Olson is presently teaching at Nova Southeastern University Huizenga School of Business \& Entrepreneurship teaching finance and economics as will as servicing as the Banking and Finance Coordinator. Dr. Olson also teaches at the graduate school teaching financial management and managerial economics at locations throughout the United States, Japan, Jamaica, Columbia, Israel, and the Bahamas. He recently conducted an international financial seminar for the faculty of La Universidad Autonoma De Bucaramanga in Bucaramanga, Columbia. Dr. Olson has conducted personal finance seminars for the Miami Dolphins football tem sponsored by the National Football League. He has presented papers at Cambridge and Oxford Universities in England. He completed residence at Oxford University as a member of the Oxford Round Table in 2004. Dr. Olson is active in the community serving on the Academy of Finance Advisory Committee on the Broward County School Board

Dr. Olson has twenty-five years experience in the field of financial management including the position of senior loan officer and V.P. with Security Pacific National Bank. He has held senior management positions with Fortune 500 companies. His background includes the position of a senior negotiator for the State of California.

He specializes in the field of Financial Management and International Finance and has written numerous papers on International Finance and is published in the field of monetary and fiscal policy under different exchange rate regimes and optimum currency areas. Dr. Olson competes as a professional golfer on the Senior Professional Golf (PGA) Tour during the summer months. His sports background includes playing basketball and baseball at San Diego State University and playing three years of professional baseball. He enjoys hunting and is a member of the National Rifle Association and an expert rifleman.

He is a decorated Korean War Veteran having served with the U.S Air Force flying combat missions during the Korean War. 


\section{REFERENCES}

1. Balassa, Bela, 1964, "The Purchasing Power Parity Doctrine: A Reappraisal," Journal of Political Economy 72: 584-596.

2. Blanchard, O. \& Quah, D. (1989). “The Dynamic Effects of Aggregate Demand and Supply Disturbances", American Economic Review 79: 655-673.

3. Bosworth, Barry. and Susan M. Collins, 1997, "Economic Growth in East Asia Accumulation versus Assimilation". Brookings papers on Economic Activity 1996, Macroeconomics

4. Chinn, Menzie, 1996, "Asian-Pacific Real Exchange Rates and Relative Prices,” Working Paper \#358 (Dept. of Economics, Univ. Calif.: Santa Cruz, July).

5. De Gregorio, J. and Holger C. Wolf, 1994. "Terms of Trade, Productivity, and the Real Exchange Rate," Working Papers 94-19, New York University, Leonard N. Stern School of Business, Department of Economics.

6. Dickey, D.A. and W. A. Fuller, 1979, "Distribution of the Estimators for Autoregressive Time Series with Unit Root," J. American Statistical Assn., 74, 427-431

7. Engle, R.F., and C.W.J. Granger, 1987, "Co-integration and error-correction: representation, estimation, and testing," Econometrica 55, 1987, 251-76.

8. Granger, C.W.J. and T. Terasvirta, 1993, "Modeling non-linearity over the business Cycle," Business Cycles, Indicators and Forecasting, ed by J. Stock and M. Watson, National Bureau of Economic Research, 1993.

9. Isard, P and Steven Symansky, 1996, "Economic Growth and Real Exchange Rate: An Overview of the Balassa-Samuelson Hypothesis in Asia," paper presented at the Seventh Annual NBER-EASE Conference "Changes in Exchange Rates in Rapidly Developing Countries: Theory, Practice, and Policy Issues," Hong Kong, June 19-22, 1996.

10. Johansen, Seren, 1988, "Statistical Analysis of Cointegrating Vectors," Journal of Economic Dynamics and Control 12: 231-54.

11. Kramer, W. Werner Ploberger and R. Alt, 1988, "Testing for Structural Change in Dynamic Models", Econometrica, vol. 56. No. 6, 1988, pp. 1355-1369.

12. Kremers, Jeroen J M \& Ericsson, Neil R \& Dolado, Juan J, 1992. "The Power of Cointegration Tests," Oxford Bulletin of Economics and Statistics, Department of Economics, University of Oxford, vol. 54(3), pages 325-48, August.

13. Samuelson, Paul, 1964, "Theoretical Notes on Trade Problems," Review of Economics and Statistics 46: 145-154.

14. Andy C.C., Kwan \& Yangru, Wu \& Fassil, Nebebe, 1996. "On the Finite-Sample Distribution of Separate Tests for Univarite Time Series Models," Departmental Working Papers__069, Chinese University of Hong Kong, Department of Economics

15. Zivot, Eric, and Chris Murray 1998, "Inference on Unit Roots and Breaks in Macroeconomic Time Series." Working Paper.

16. Zivot, Eric, Charles Nelson and Richard Startz 2003,'Improved Inference for the Instrumental Estimator", Working Paper. 
Table 1: ADF Unit Root Tests

ADF Unit Root Tests

Exchange Rates

Country

Malaysia

Philippines

Thailand

Indonesia

Inflation

China

Hong Kong

Japan

Indonesia

Korea

Philippines

Singapore

Thailand

Malaysia

Taiwan

1983-2002

1983-2002

1991-2002

1991-2002

1983-2002

1983-2002

1991-2002

1991-2002

1991-2002

1991-2002

Total Factor Productivity

Indonesia

Malaysia

Philippines

Thailand

1983-2000

1991-2000

$1983-2000$

1991-2000
ADF

Critical

Values

$-1.62$

$-1.62$

$-1.62$

$-1.94$

$-1.62$

$-1.62$

$-1.7732$

$-1.6363$

$-1.9049$

$-1.62$

$-1.62$

$-1.2565$

$-2.56$

$-1.2057$

$-1.62$

$-1.8911$

$-1.62$

$-1.8916$

$-1.94$

1.1953

2

2

$\begin{array}{llll}2 & -1.62 & -1.7598 & * * * \\ 2 & -1.62 & -1.7422 & * * * \\ 2 & -2.56 & -3.1797 & * * * \\ 2 & -1.94 & -1.1521 & \end{array}$

Schmidt \& Phillips

$\begin{array}{cc}\text { Criticall } & \text { Test } \\ \text { Value } & \text { Results }\end{array}$

$\begin{array}{ll}15 & -9.0836 \\ -15 & -6.6822 \\ -15 & -9.0963\end{array}$

$-25.2 \quad-9.9306$

$-18.1 \quad-7.5163$

$-25.2 \quad-3.4253$

$-15.1 \quad-15.1075 \quad * * *$

$-18.1 \quad-3.1806$

$-18.1 \quad-15.8408 \quad * * *$

$-18.1 \quad-8.5854$

$-15 \quad-12.0776$

$-25.2 \quad-12.6754$

$-18.1 \quad-5.4169$

$-15 \quad-14.9544$

$-15 \quad-11.9458$

$-15 \quad-12.0776$ 
Table 2: Cointegration Tests

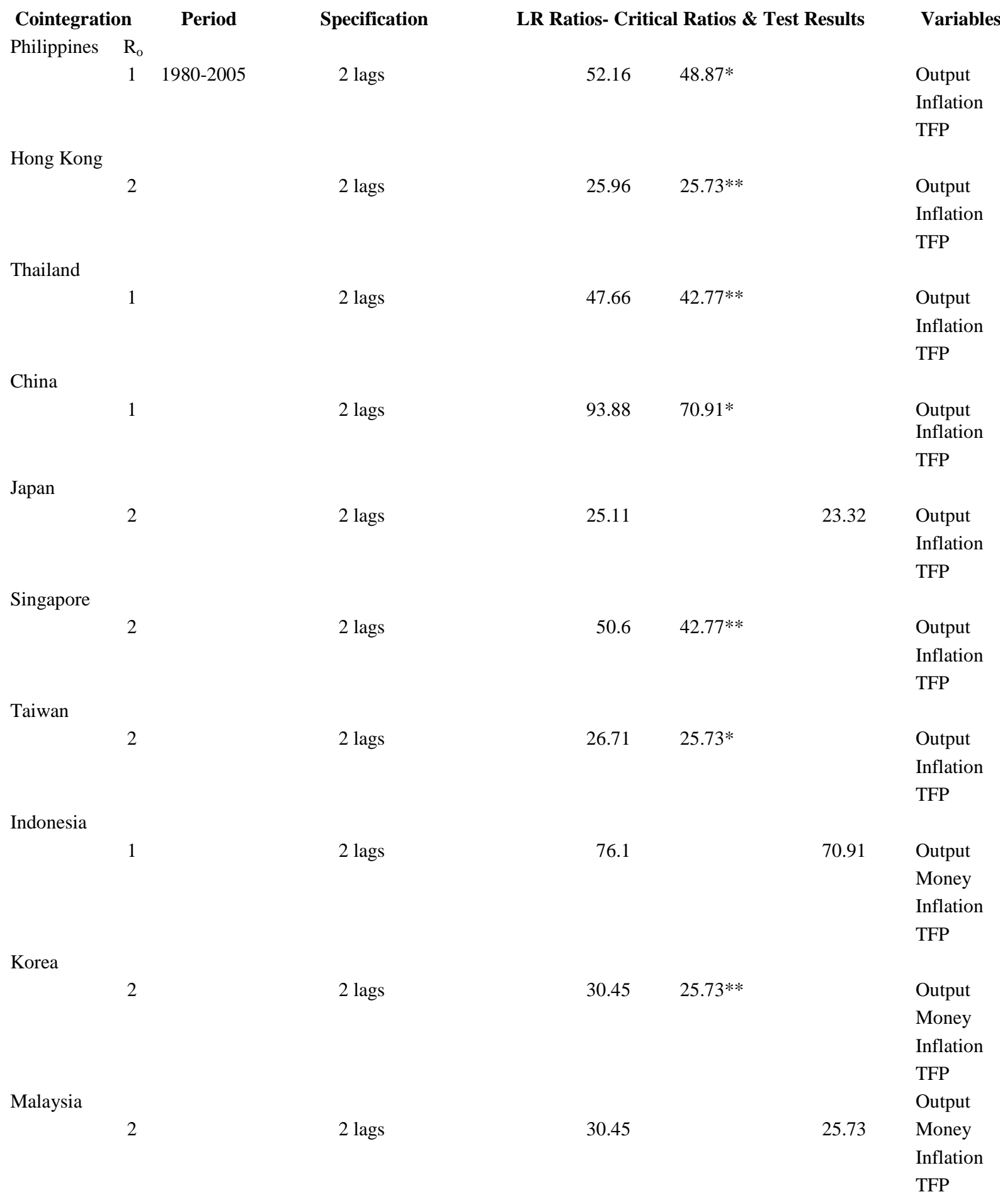


Table 3: Cointegration Tests With Oil Variable

$\begin{array}{rcl}\text { Cointegration } & \text { Period } & \text { Specification } \\ \text { Philippines } & 1980-2005 & 2 \text { lags } \\ \mathrm{R}_{\mathrm{o}} & & \text { With Oil Prices }\end{array}$

1

\begin{tabular}{|c|c|}
\hline Hong Kong & 2 lags \\
\hline & With Oil Prices \\
\hline \multirow[t]{2}{*}{ Thailand } & 2 lags \\
\hline & With Oil Prices \\
\hline \multirow[t]{2}{*}{ China } & 2 lags \\
\hline & With Oil Prices \\
\hline \multirow[t]{2}{*}{ Japan } & 2 lags \\
\hline & With Oil Prices \\
\hline
\end{tabular}

$\begin{array}{lll}\quad \text { Singapore } & 2 \text { lags } \\ & \text { With Oil Prices }\end{array}$

2

Taiwan

2 lags

With Oil Prices

Indonesia

1

2 lags

With Oil Prices

Korea

2

Malaysia

2

2 lags

With Oil Prices

2 lags

With Oil Prices
LR Ratios- Critical Ratios \& Test Results
52.16

$\begin{aligned} & 48.87 * \\ 21.04 & 20.16^{*}\end{aligned}$

25.96

$\begin{array}{ll}25.73^{* *} \\ 21.09 & 20.16^{* *}\end{array}$

47.66

$\begin{array}{ll} & 42.77 * * \\ 18.93 & 17.98\end{array}$

93.88

$70.91^{*}$
$49.24 \quad 40.78^{* *}$

25.11

$$
74.6040 .78^{* *}
$$

50.6

$\begin{aligned} & 42.77 * * \\ 26.58 & 24.69^{* *}\end{aligned}$

26.71

$25.73 *$

$19.40 \quad 17.98$

76.1

$$
22.9320 .16^{* *}
$$

Variables

Output

Oil Pres

Inflation

TFP

Output

Oil Pres

Inflation

TFP

Output

Oil Pres

Inflation

TFP

Output

Oil Pres

Inflation

TFP

23.32 Output

Oil Pres

Inflation

TFP

Output

Oil Pres

Inflation

TFP

Output

Oil Pres

Inflation

TFP

$70.91 \quad$ Output

Oil Pres

Inflation

TFP

Output

Oil Pres

Inflation

25.73 Oil Prcs

30.45

$12.30 \quad 17.98$

Inflation

TFP 
Figure 1: VECM Forecast Error Impulse Responses

Responses of Real Exchange Rates to Supply (Total Factor Productivity) shock based on an unrestricted VAR with $95 \%$ Hall bootstrap confidence intervals using 2000 bootstrap replications.

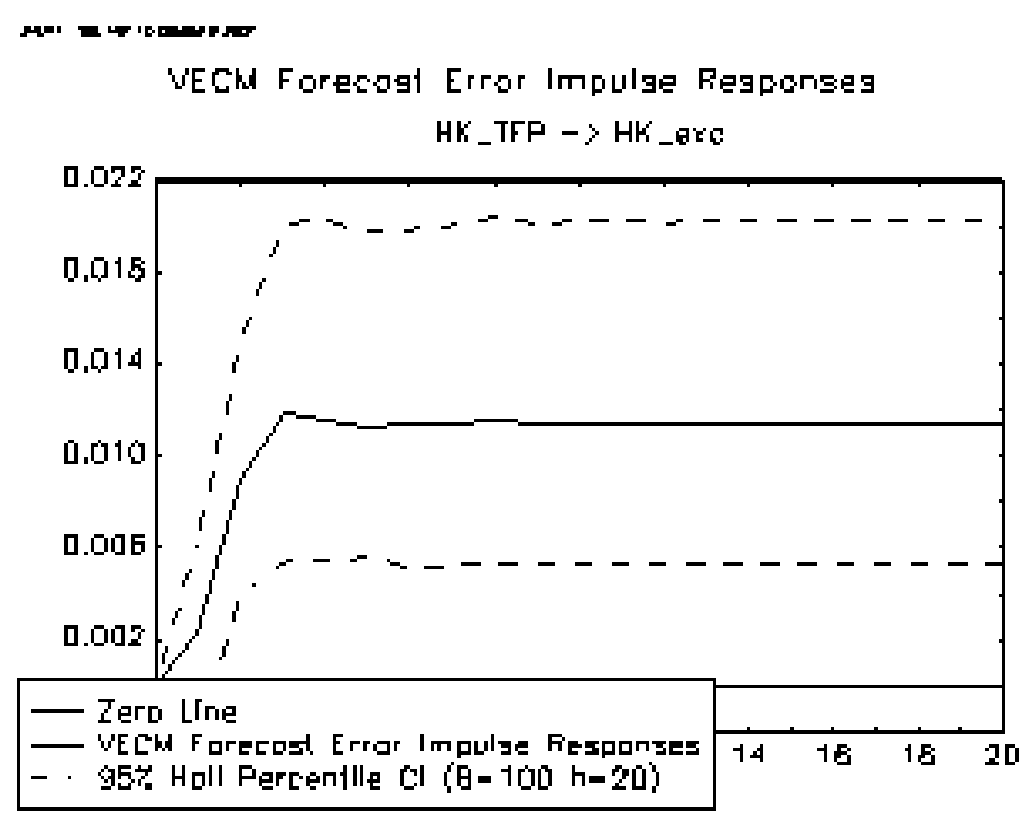

A

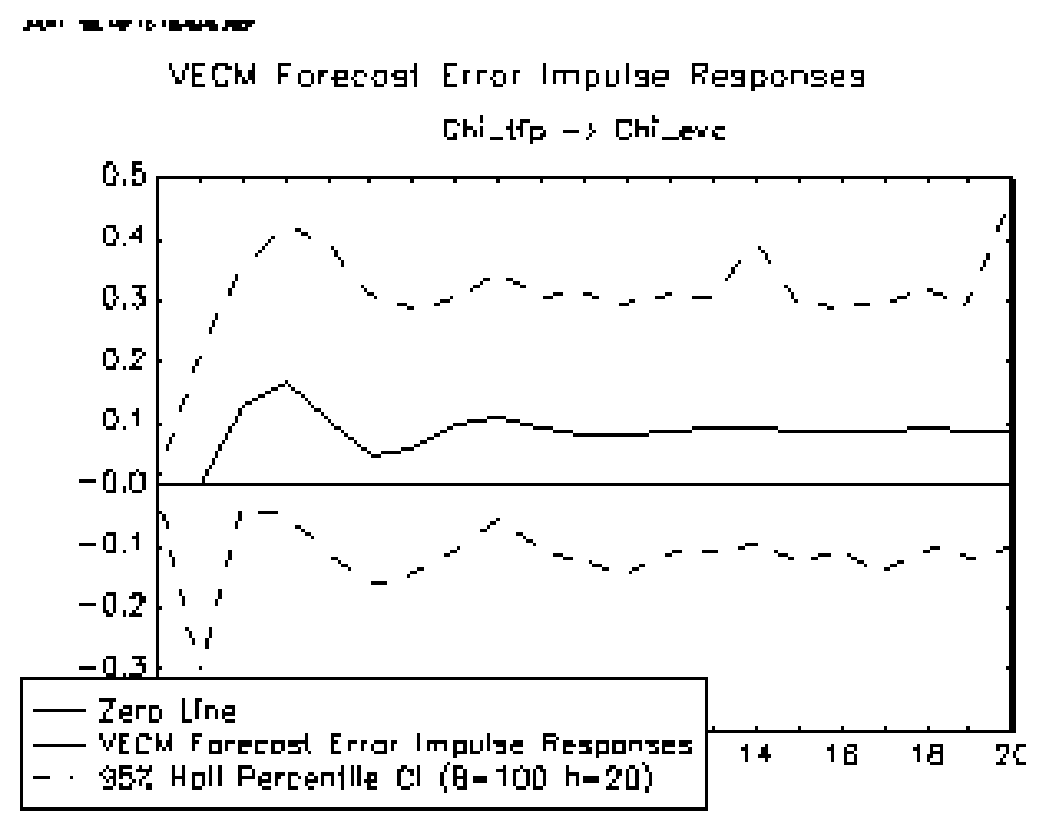


Figure 2: VECM Forecast Error Impulse Responses

Responses of Real Exchange Rates to Supply (Total Factor Productivity) shock based on an unrestricted VAR with $95 \%$ Hall bootstrap confidence intervals using 2000 bootstrap replications

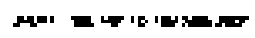

VEChd Forecogl Error Impulge Regponseg

Siny__TFP -> Sing_ere

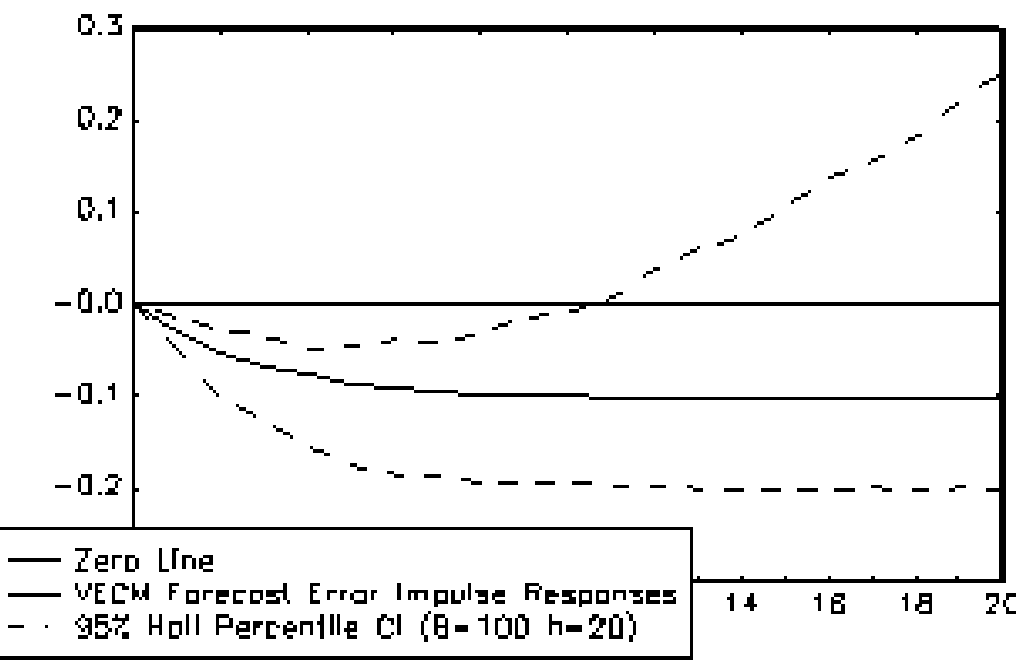

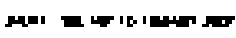

VEChd Forecogi Error Impulge Regponseg

ROK_TFP - $\mathrm{Kor}$ _Pro

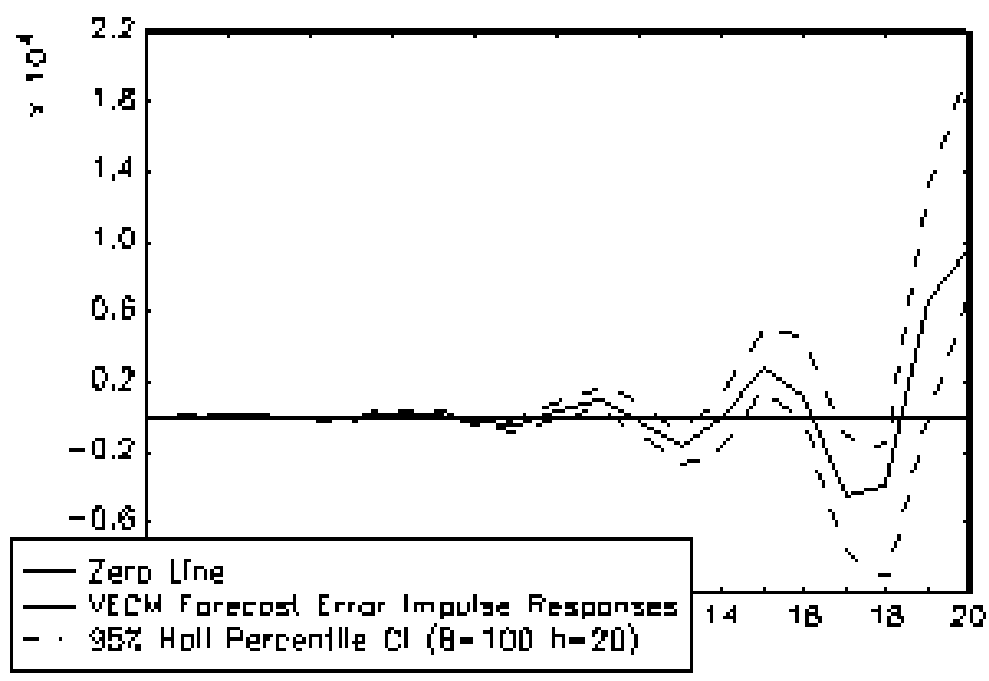


Figure 3: VECM Forecast Error Impulse Responses

Responses of Real Exchange Rates to Supply (Total Factor Productivity) shock based on an unrestricted VAR with $95 \%$ Hall bootstrap confidence intervals using 2000 bootstrap replications

mas =

VEChd Forecogl Error Impulge Regponseg

Thor_TFP - > Thal_erc
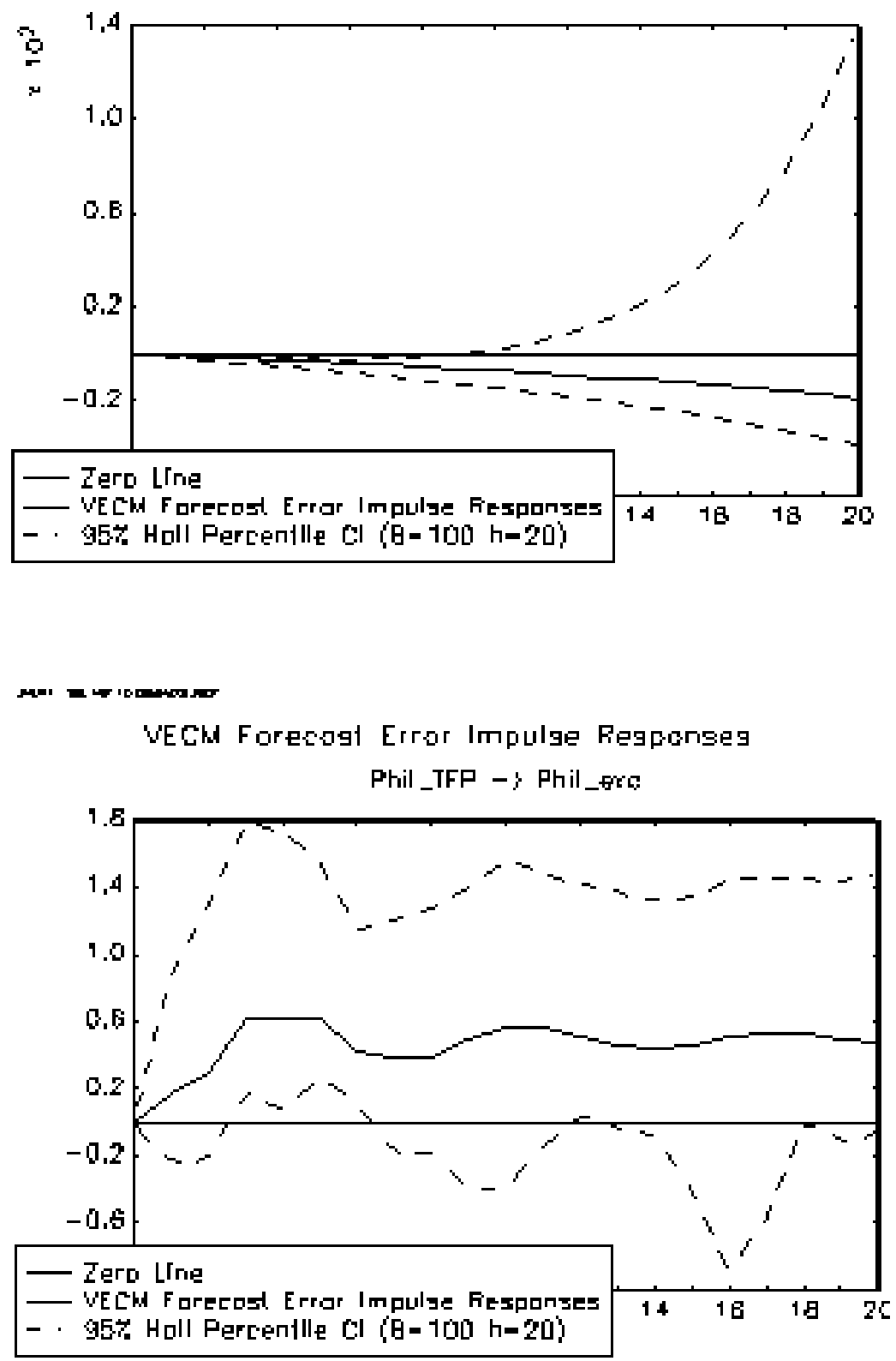
Figure 4: Cusum Tests of Model for Exchange Rate and Total Factor Productivity Series
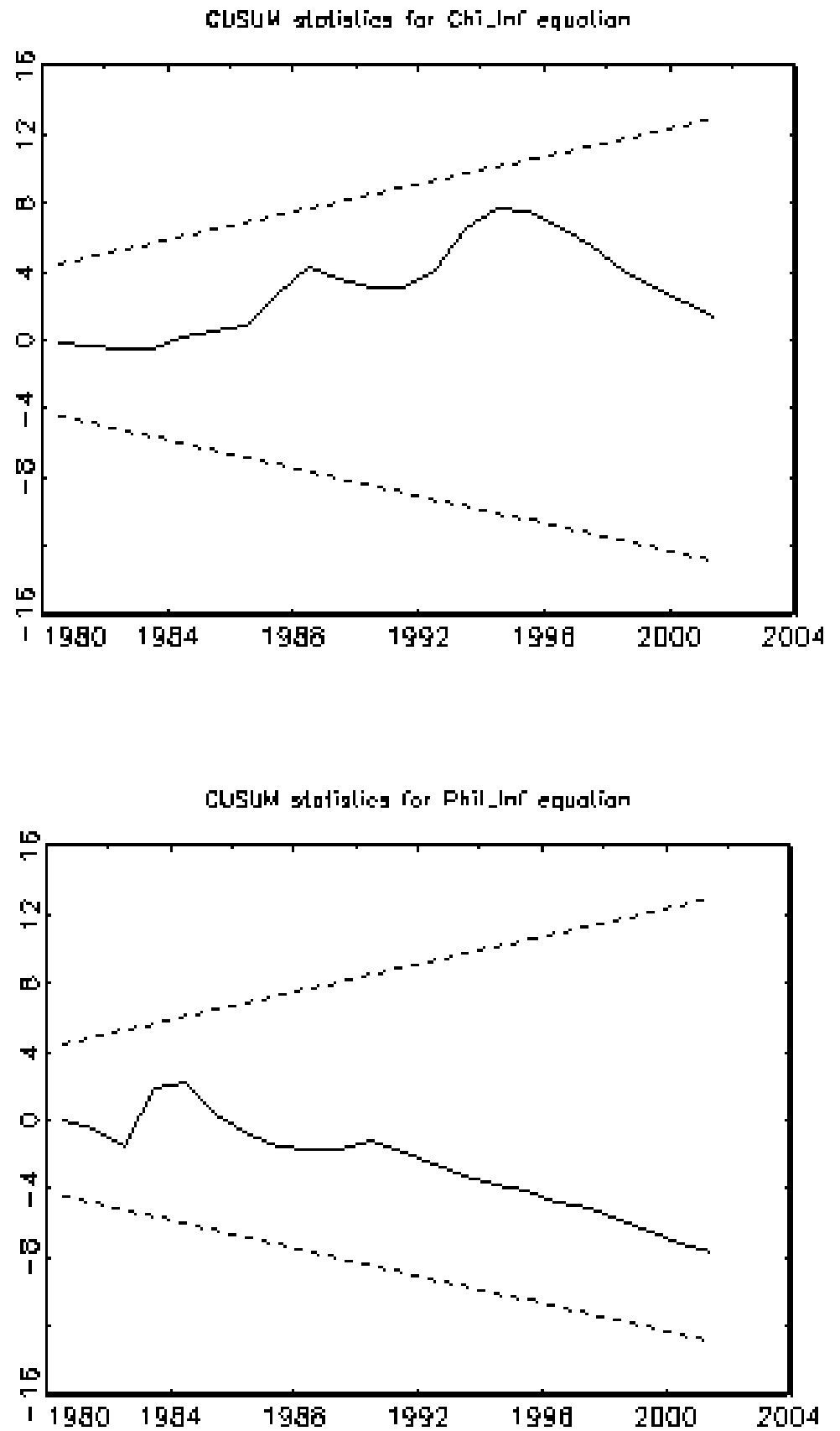
NOTES 